\title{
TOWARDS BRAZIL AND CHINA CROSS-CULTURAL UNDERSTANDING AND TRANSNATIONAL COOPERATION
}

\author{
João Cezar de Castro Rocha ${ }^{1}$ \\ Jiang Hongxin ${ }^{2}$ \\ Zeng Yanyu ${ }^{3}$ \\ Ren Haiyan ${ }^{4}$
}

This special issue of the Journal of ABRALIC, Cultural and Literary Ties Between Brazil and China, was made possible by the collaborative effort of two institutions: State University of Rio de Janeiro (UERJ) and Hunan Normal University (HNU). It is not the first outcome of this emerging partnership, and certainly will not be the last. Rather, other projects will soon be developed and announced. Indeed, in a globalized world nothing is more urgent than building cultural bridges between countries in order to foster cross-cultural understanding as well as to promote transnational cooperation.

Cultural and Literary Ties Between Brazil and China is divided into two sections.

The first section starts with Professor Bethania Mariani's important essay, and it comprises texts whose main aim is to introduce relevant aspects of Brazilian culture to a foreigner readership. This is a key point in our common endeavor undertaken by UERJ and HNU: we are fully aware that cross-cultural understanding implies an openness toward the other's culture. We decided to commit ourselves to the creation of a fruitful and harmonious long-term collaboration between Brazilian and Chinese cultures. As a further step in this road, the second section proposes an ambitious and at the same time an indispensable aim, namely, introducing contemporary Chinese literary theory and cultural criticism to a wide Latin American audience. Cross-cultural understanding has to be a two-way street: one must give and take, teach and learn, talk and listen as inextricable parts of the gesture of transnational dialogue. This section starts with Professor Jiang Hongxin's insightful essay. This special issue also introduces to Brazilian readers some of the finest and most distinguished scholars of Chinese contemporary academia.

We are already planning new projects in order to deepen this most needed initiative: rendering Brazilian and Chinese philosophical, literary and critical traditions known in both countries. We are determined to challenge the "fallacy of cultural incommensurability", following the lead offered by Zhang Longxi, for "the fact is that similarities and differences exist everywhere, within one culture as well as between or among cultures" (Longxi, 2007, p. 17). Moreover, if, in Shi Er's words, "the universe is composed of twin worlds" (Er, 2019, p. 1), then, an ethics of cross-cultural dialogue implies privileging difference instead of repetition. Antonio Candido, a leading Brazilian literary critic, once observed that "studying Brazilian literature means studying comparative literature" (Candido, 2004, p. 230). In the same vein, José Luís Jobim has suggested that "in Brazil comparative literature was not developed as something alien to national literatures" (Jobim, 2019, p. 39). It seems that the theoretical ground for our endeavor has already been established. Indeed, there is no better way to bring countries

\footnotetext{
${ }^{1}$ Universidade do Estado do Rio de Janeiro - UERJ, Rio de Janeiro, Rio de Janeiro, Brasil; https://orcid.org/0000-0001-5053-6768; jccr123@yahoo.com.br

${ }^{2}$ Hunan Normal University, Changsha, China 410081; https://orcid.org/0000-0002-8659-2654; jhxin@hunnu.edu.cn

${ }^{3}$ Hunan Normal University, Changsha, China 410081; https://orcid.org/0000-0001-9523-9935; yzeng2646@hunnu.edu.cn

${ }^{4}$ Hunan Normal University, Changsha, China 410081; https://orcid.org/0000-0002-1654-3750; haiyren@hunnu.edu.cn
} 
together than establishing cultural ties and organizing common research projects; for producing knowledge in one breath is the strongest way of creating long-term relationships.

\section{WORKS CITED:}

CANDIDO, Antonio. "Literatura comparada". In: Recortes. Rio de Janeiro: Ouro sobre azul, 2004. p. 229-233.

JOBIM, José Luís. Literatura comparada e literatura brasileira: circulações e representações. Rio de Janeiro : Makunaima; Boa Vista: Editora da Universidade Federal de Roraima, 2020. LONGXI, Zhang. Unexpected reading across cultures affinities. Toronto: Toronto University Press, 2007.

ER, Shi. The Book of twin worlds. Trans. Alan Z.X. Tan. Beijing: The Commercial Press, 2019.

\section{Statement of authorship and responsibility for the published content}

The authors clarify that the writing of this article, in all its parts, was a collaborative work.

João Cezar de Castro Rocha is Full Professor of Comparative Literature at the State University of Rio de Janeiro and a researcher at the National Council for Scientific and Technological Development - CNPq. Castro Rocha is also a Fellow of the Alexander von Humboldt Foundation. Castro Rocha has received Distinguished Fellowsips and Visiting Professorships from several institutions in the United States, Europe, and Latin America. Among others, from Princeton University, Cambridge University, Universidad del Claustro de Sor Juana, Universidade da Coruña, Oxford University, Yale University, University of Massachusetts-Dartmouth, University of Wisconsin-Madison, Universidad de la República, Freie Universität-Berlin. Author of 13 books and editor of more than 20 titles. For further information see http://lattes.cnpq.br/2996791931732673.

Jiang Hongxin is Full Professor of English language and literature and Executive President of Hunan Normal University, Editor-in-Chief of Foreign Languages and Cultures and Journal of Foreign Languages and Cultures, Distinguished Expert of Government Special Allowance by State Council 2011, Vice Chairman of Teaching Steering Committee for Foreign Language and Literature Specialty in Colleges by the Ministry of Education 2018-2022, Chair of Sub-Committee on Teaching Guidance for English Majors by the Ministry of Education 2018, Vice Chairman of National Steering Committee for Postgraduate Education of Translation by Academic Degrees Committee of State Council 2016. For further information see https://fsc.hunnu.edu.cn/info/1224/4532.htm

Zeng Yanyu is currently Professor of American Studies and Comparative Literature and dean of the Foreign Studies College at Hunan Normal University. She is the executive editor-in-chief of the Journal of Foreign Languages and Cultures. She serves as the Executive Member of the International American Studies Association, the Standing Council Member of China English Literature Association, the Vice President of Hunan Translators Association and the Vice President of Hunan Comparative Literature and World Literature Association. She worked as a Visiting Scholar at the University of Toronto (2000), a Visiting Scholar at Emory University (2005-2006) and a Visiting Scholar at Columbia University (2014-2015). Professor Zeng specializes in British and American literature and cultural studies, and has contributed to various journals a large range of essays and articles. For further information see https://fsc.hunnu.edu.cn/info/1224/4532.htm

Ren Haiyan is Associate Professor of English at Hunan Normal University, managing editor of Foreign Languages and Cultures and Journal of Foreign Languages and Cultures. For further information see https://fsc.hunnu.edu.cn/info/1225/3871.htm 